\title{
THE QUESTION OF THE MINIMUM LUGGAGE ALLOWANCE IN THE BRAZILIAN AIR TRANSPORT UNDER THE PERSPECTIVE OF THE ECONOMIC REGULATION THEORY
}

\author{
MARIA MARCONIETE FERNANDES PEREIRA ${ }^{1}$ \\ Matheus Jeruel Fernandes CATÁO ${ }^{2}$ \\ JOSÉ ANTÔNIO ROCHA ${ }^{3}$
}

\section{ABSTRACT}

The present work aims to investigate the regulation of luggage allowance in the Brazilian civil aviation sector based on the Economic Regulation Theory proposed by George Stigler. This is a bibliographic study, with emphasis on Brazilian and foreign doctrines on the economic regulation theory as well as on the regulation of the air transport sector. The method used was predominantly deductive, starting from general analyses on the economic regulation theory and the air transport sector to the applicability of the Economic Regulation Theory into Resolution 400/2017. In conclusion, we understand that, contrary to what has become popular, the end of the regulation for luggage allowances in Brazil, as a measure of economic liberalization, benefits the airline industry as a whole, favoring competition, consequently, consumers.

Key words: Economic Regulation Theory. Civil Aviation. Luggage allowance.

\section{INTRODUCTION}

The civil aviation sector is always a worldwide subject for relevant discussions, especially with regard to the regulatory part. The relatively low number of companies on the market, the high cost of operations and government incentives are factors that hinder free competition.

1 Doutora em Direito Público pela Universidade Federal de Pernambuco. Mestre em Ciências Jurídicas pela Universidade Federal da Paraíba. Professora Titular de Direito e do Programa de Pós-Graduação em Direito/Mestrado do Centro Universitário de João Pessoa (UNIPÊ). E-mail: mmarconiete@gmail.com.

2 Advogado. Mestrando em Direito e Desenvolvimento Sustentável pelo Centro Universitário de João Pessoa, Paraíba. Brasil. (PPGD/UNIPÊ). Pós-Graduando em Direito Tributário. E-mail: matheus_jeruel@hotmail.com.

3 Mestrando em Direito e Desenvolvimento Sustentável pelo Centro Universitário de João Pessoa, Paraíba, Brasil (PPGD/ UNIPÊ). E-mail: jantoniorocha@outlook.com. 
In effect, the issue involves the role of economic regulation, notably with regard to consumer protection.

The Brazilian regulatory system went through several regulatory phases throughout the development of the civil aviation market, one of the main marks of this history being the creation of the National Civil Aviation Agency (ANAC). Since its creation, it has already issued several regulatory acts for the sector, proving to be an important instrument for the regulation of the Brazilian aviation market.

Recently, another regulation was issued, which gained great national repercussion: the end of the luggage allowance. This regulatory initiative guaranteed passengers the right to have checked luggage weighing proportionally to the size of the aircraft. As of the edition of this regulation, the baggage check could be charged separately, with the alleged objective of cheapening the ticket price for those passengers who did not checked their luggage. This decision was the target of several criticisms, mainly in the consumer protection agencies, which saw the measure as a setback.

Economic regulation, in turn, is based on the belief that full liberalization may not be as advantageous, notably due to the existence of market failures. Therefore, some theories were created to explain the regulatory phenomenon, such as the public interest theory, which argues that economic regulation exists in the interest of everyone and the capture theory, proposed by Stigler, who argues that, in fact, economic theory serves exactly the regulated companies that capture the regulatory entities.

That said, the objective of this paper is to investigate, from the point of view of economic regulation theories, the end of the luggage allowance in the Brazilian civil aviation from the formulation of the following question: Having the phenomena described by the Theory of Captura as basis, the end of the baggage allowance rule would or not be beneficial to the brazilian air sector? The research method predominantly used will be the deductive method, where from an analysis of the theories of economic regulation, emphasizing the theory of capture, about the regulation of the airline sector in Brazil, starting with a specific analysis about the regulation of the luggage allowance in Brazilian civil aviation and its allocation in the capture theory.

The predominantly used research technique will be the bibliography review, adopting ANAC Resolution 400/2016 as a primary source, secondary sources to Brazilian and foreign doctrine, with emphasis on the air sector and materials related to the theories of economic regulation, having as reference the George Stigler's work "Theory of Economic Regulation".

The first topic dedicated to a thorough analysis of the regulation theory proposed by Stigler, by verifying its main positive and negative points, starting with an analysis on the regulation in the airline sector, with emphasis on the United States of America. In this referred country, the matter on regulation was the first initiative. Subsequently, a historical view of the regulation of the Brazilian air market will be demonstrated with a more in-depth analysis of the end of the luggage allowance. After this brief analysis, we will try to make a correlation between the elements of the capture theory and the regulation of the luggage allowance within the Brazilian law, seeking to understand the similarities and the distinctions between them. 
By the final part of this work, the hypothesis will develop towards the promotion of economic freedom, which is the goal of the end of luggage allowances; although a priori it can demonstrate a relationship with the capture, a posteriori it can mean progress, considering that it promotes free competition, thus reducing the possibilities of capture.

\section{THEORY OF ECONOMIC REGULATION: EVOLUTION AND PRIMARY CONCEPTS}

The movement favouring state intervention on the economic domain arose between the end of the 19th century and the beginning of the 20th century. It is clear that the self-regulation model proposed by Adam Smith could trigger what is commonly named "market failure". In this case, the intervention would serve to maintain the Pareto balance of perfect competition, which cannot occur in the presence of these failures (STIGLITZ; ROSENGARD, 2015).

Stiglitz; Rosengard (2015) point out six market failures considered to be basic. The first is imperfect competition, which occurs when, for various circumstances, the offer is concentrated in a monopoly or oligopoly. The second is the existence of public goods, which consists of those goods where demand is not controlled, such as the provision of national security or navigation channels. The third market failure is presented by the externalities, which are facts that are alien to the transaction itself but that interfere with it. The fourth failure is the incomplete markets, which are situations in which there is no supply even if the costs do not exceed the benefits. The fifth failure consists on information failures, which are the situations in which buyers do not have as much knowledge as the sellers about the products purchased and, finally, unemployment, inflation and imbalance.

Regarding economic regulation, Moncada (2007, p. 45) and Chang (1997) note that, indirect intervention goes through three major phases from the post-war period. The first phase is named the "Era of Regulation", which lasted between 1945 and 1970, marked by a strong interventionist character to guarantee the public interest; the second phase is named the "Transition Period", between the 1970s and 1980s; and, finally, "the Era of Deregulation" that began in the 1980s and continues to this day.

In the transition period, from 1970 to 1980 , it was questioned whether the welfare government could consider the public interest an absolute truth. Indeed, government failures arose. In this sense, Oliveira $(2015$, p. 139) argues that the key feature is found in state paternalism, which ends up reducing the individuals' private autonomy and "regulatory asphyxiation", where excessive regulation ends up preventing the exercise of economic activity. According to the author "Regulatory asphyxiation" is the term used by the doctrine to designate "excessive regulation, which makes the economic activity unfeasible, as well as the absence of regulation, compromising equality in the market full of failures" $(2015$, p. 21). Also, that it is "the infeasibility of exercising economic activities due to the excess of state restrictions, configuring, in some cases, indirect expropriation of the right to exercise a certain economic activity" (2015, p. 140). 
There are still two major arguments that developed from the analysis of government failures, the first of which is the rent seeking theory: the monopolies are created through governmental regulatory impositions, being a direct consequence of this and not an evil to be drifted away. And the theory of regulatory capture or capture theory, a direct consequence of regulation would be the control of regulation by the interests of the regulated sector, to the detriment of consumers, and that is the theory adopted for this research (CHANG, 1997, p. 740).

The capture theory, defended, initially, by the American economist George Stigler, arises out of the simple assumption that the regulation is a product and, as any other, can be easily traded on the market. The only difference between the usual products and regulation is that in the second one the market structure is defined by the political process and not by the economic one (CARRIGAN; COGLIANESE, 2016, p. 4). In other way, it means that those who offer the regulation have a coercive power over those who "consume" them.

The "consumers" of regulation are the economic sectors that can benefit from it. According to the author, there may be four ways of regulatory politics that an economic sector can take advantage of. The main one is the direct grant, where the State gives money directly to the economic agents, followed by the state restriction for the entry of new competitors on the market by both the adoption of strict rules for it or even the full prohibition; restriction that may affect the producers of substitute products, such as margarine restrictions to benefit the butter industry or ethanol restrictions to benefit the gasoline industry and, by the end, price politics (STIGLER, 2017).

In his articles, published for the first time in 1971, Stiglitz emerged as one of the most important critics of those who justified the state intervention as an instrument for consumers protection and mitigation of competition imbalance, and furthermore evaluated the state action by its intention and not its results. In other words, those who defended the intervention from what it should be and not what it actually was (FIANI, 2004). In contrast, Stigler studied the regulation from a realistic point of view and in accordance with its consequences. Additionally, he brought several empirical examples to justify his point.

Another critic of this "romantic" view of state regulation was Richard Posner (2017) that, when stating critics over the public interest theory, told that, among other characteristics, there are no means to guarantee that the public opinion would translate into legislative action for the public interest. Additionally, according to the author, however there may be problems on Stigler's theory, it may be the most correct one, since it is the one that illuminates other areas beyond the market behavior.

After Stigler and Posner, several others studied the capture theory. The one that most stood out, according to Fiani (2004), were Peltzman with his "result idea" from 1976, Becker in 1983 with his "efficient regulation" idea and Loffont and Tirole with their "cost function specification of the regulated form" in 1993. However, for this research, considering also its juridical point of view, we will adopt the general ideias proposed by Stigler.

\subsection{ECONOMIC REGULATION IN THE NORTH AMERICAN AIR TRANSPORT SECTOR}

In the United States, air transport regulation began in the 1920s with the so-called "Kelly Act" which consisted of direct government subsidies to airlines. After that, in 1938, Civil Aeronautics Board was created, a regulatory agency responsible for the sector that, among other 
restrictions, prohibited price competition between companies, still with the focus of protecting the sector and promoting its development (CHMURA, 1984 )

Although it is easy to conclude that the few companies existing on the market at the time have benefited from this regulation, both by state aid and the restricted competition, reinforcing the capture theory proposed by Stigler. Chmura (1984) states that American civil aviation would not have developed or stabilized so quickly without government assistance, however, the high growth of companies was justified by government subsidies. From it, complaints about the sector began, causing a movement of deregulation, which started in the 1960s.

Gowrisankaran (2002) states that, since the beginning of deregulation and the consequent freedom of route operation and pricing by companies, the North American air market faced considerable growth. According to the author, the number of passengers between the years 1975 and 2000 more than tripled, while ticket prices fell by less than half, showing that the self-regulation market mechanisms, in several cases, promote growth.

However, it is important to highlight that, due to the peculiarities of the sector, some type of regulation becomes necessary and shows positive effects. One example is the regulation to create barriers to develop monopolies. Leaving mergers and acquisitions of free companies at the discretion of economic agents can often promote the creation of monopolies, which is disadvantageous for consumers.

\section{THE REGULATION OF BRAZILIAN AIR TRANSPORT: INTRODUCTORY REMARKS}

According to the Administrative Council for Economic Defense (CADE), this means of transportation, following the global trend of the time, was strongly regulated by the State (2019, p. 3). Its historical milestones in Brazil point out that the first companies and regular airlines date from the 1920s, from the last century. In 1931, the Department of Civil Aviation (DAC) was created, initially called the Department of Civil Aeronautics, predecessor to ANAC (2006) and in 1938 the Brazilian Air Code was published.

The regulation of the air transport market for passengers in Brazil, according to Oliveira (2007), has undergone two major regulatory reforms. The first, started in the 1970s, known as "Controlled Competition" and the second, starting in the 1990s, named "Flexibility Policy", that is, followed the same order as the United States. The first was marked by intense regulation, including price controls, while the second reform was characterized by greater market liberalization. For Oliveira (2007), these two major reforms can be subdivided into six stages of regulation: the first stage, the regulation as an industrial policy for development; the second, regulation as an active stabilization policy; the third, liberalization as an inactive stabilization policy; the fourth, liberalization as a constraint on the stabilization policy; the fifth, quasi-deregulation and the sixth, re-regulation, which started in 2003.

Clearly, an abrupt process of economic deregulation was not applied to the aeronautical modal, that is, the Brazilian State did not choose to adopt a consolidated package of libe- 
ral measures, choosing a gradual evolutionary process. In 2005, after the creation of ANAC, several other measures were taken to stimulate competitiveness and free competition in the sector. Among them, Guaranys (2010) points to the establishment of pricing freedom and of supply by law in the strict sense. Another important measure, the restriction of the role of the regulatory agency when indications of competitive illicit acts were identified, where its role would be only to communicate it to the competent authority, in that case, the Brazilian competition defense system.

Finally, it should be noted that an important chapter in the history of regulation of the Brazilian airline sector occurred between 2018 and 2019, with the edition of Provisional Measure $863 / 2018$ and its subsequent conversion into Law No. 13,842/2019. This regulation modified the Brazilian Aeronautical Code, allowing companies with $100 \%$ foreign capital to enter the national market, provided that they have their headquarters and administration in the country. Previously, 4/5 of the capital should belong to Brazilians and the management functions should also be exercised by Brazilians.

\subsection{THE LUGGAGE ALLOWANCE ISSUE}

The National Civil Aviation Agency (ANAC), from 2000 until the adoption of Resolution No. 400/2016, obliged air transport companies to offer their passengers a minimum luggage allowance. It corresponded to 23 kilos, on domestic flights on airplanes with a capacity above 31 passengers, being 30 kilos for passengers flying in first class, 18 kilos for aircrafts of 21 to 30 seats and 10 kilos for aircrafts of up to 20 seats.

To delimit the General Conditions of Air Transport and build the Resolution 400/2016, the National Civil Aviation Agency used Regulatory Impact Analysis (RIA) ${ }^{4}$, in which it assessed that the sector's regulatory proposals should address both the issue of freedom of establishment tariffs and differentiation of services to air operators and also the point of mandatory maintenance of the right to franchise.

This RIA is the result of research by the Agency since 2013 and, with regard to the baggage allowance, it is guided by the guidelines of the International Civil Aviation Organization (especially Doc. 9587) and international experience on the subject. RIA's studies culminated in Public Hearing No. 03/2013, in which several consumer protection agencies - such as the National Consumer Secretariat (SENACON), São Paulo Consumer Protection and Defense Attorney (PROCON/SP) and Consumer Guidance Service (SOS Consumidor) - argued that the separate purchase of the baggage delivery service would harm consumers. However, ANAC noted that state intervention in the baggage allowance rules did not offer economic efficiency gains to passengers and prevented the development of the air carrier business model. In addition, the stipulation of baggage allowance in this mode lacked technical fundamentals, since old regulations on the subject needed to adapt to the new context of civil aviation, according to parameters of a market economy that is both more evolved and mature, able to assimilate the best ones competition practices in an increasingly competitive market (BRA- 
SIL, 2013). For these reasons, the Agency concluded that the free franchise model was more beneficial to the sector, both in relation to domestic and international transport.

In 2016, with the maturing of debates ${ }^{5}$, the Resolution No. 400 gave a new shape to the general conditions applicable to the regular air transportation of passengers (domestic and international), such issues related to the provision of the service; alteration and termination of the air transport contract by the passenger; check-in and presentation for boarding.

Specifically regarding our object of study, the standard defined that the transportation of checked luggage is an accessory contract and companies are free to determine the rates applicable to their respective services. Considering that, the checked luggage allowance was no longer mandatory. On the other hand, hand luggage per user, established at 10 (ten) kilos per person, remained mandatory - the previous estimations was only 05 (five) kilos.

Resolution No. 400/2016 became effective in March 2017, however the provisions on checked luggage were suspended by decision of the Federal Court ${ }^{67}$. Consumer agencies promoted Public Civil Actions claiming that the exclusion of the luggage allowance excessively burdened the consumer and caused an imbalance in consumer relations.

The Brazilian Bar Association and the Municipal Department of Consumer Protection and Defense - PROCON, of the Municipality of Fortaleza (author of Public Civil Action No. 0816363-41.2016.4.05.8100), reasoned that the regulatory body when issuing the Resolution failed the provisions of article 734 of the Civil Code ${ }^{8}$, since the transport of people would include, in addition to the passenger himself, the luggage. For them, the national legal system perceives the transportation of luggage as an accessory provision immanent to the transportation of people and, therefore, the conclusion established by article 13 of Resolution 400/2016 from ANAC would not be correct. There would be a transfer of responsibility and operation costs of the luggage clearance service to the consumer, without requiring any compensation from the carrier.

In the merit judgment, the Federal Court ruled that the request was unfounded. First, by observing that the Consumer protection agencies described that, necessarily, the modifications of Resolution No. 400/2016 would cause losses to air transport users, however such an explanation is not immediately extracted from any provisions of the normative act depleted. In fact, as will be shown in a timely topic, the path of economic deregulation of air transport has proved to be effective in the interests of consumers. Secondly, it was found that the burden of carrying luggage in contracts for the transport of people in general (Article 734 of the Civil Code) does not oblige the carrier to take any and all luggage, in any quantity or weight.

5 Verify other public hearings that contributed to the formation of Resolution No. 400/20016 at: https://www.anac.gov.br/ participacao-social/consultas-publicas/audiencias-encerradas/audiencias-publicas-encerradas-de-2013 .Accessed: May 21, 2020.

6 Four Public Civil Actions (ACP) were processed against ANAC, with the Superior Court of Justice (STJ) defining that the 10th Federal Court of the Judiciary Section of Ceará was the competent judge for the trial (asserted jurisdiction). Of the other three ACPs, one had been filed by the Consumer Protection and Defense Management of Pernambuco (Procon / PE), and the other, proposed by the Brazilian Bar Association, was being processed at the 4th Federal District Court. The fourth, from the 22nd Federal Civil Court of the São Paulo Judicial Subsection, proposed by the Federal Public Ministry. It was in the midst of this last Public Civil Action that a preliminary injunction remained to suspend articles 13 and 14 of Resolution 400/2016.

7 According to data available on the ANAC website, airlines have only effectively applied the unbundling of baggage handling services as of June 2017. See: https://www.anac.gov.br/assuntos/setor-regulado/empresas/envio-de-informacoes/ tarifas-aereas-domesticas- 1 .

8 Brazilian Civil Code (Law No. 10.406 / 2002), article 734: The carrier is liable for damages caused to the persons transported and their luggage, except for reasons of force majeure, any clause excluding liability being null and void. 
Thus, it is legitimate for the provider to stipulate reasonable conditions of service and, in the case of air transport, it is legitimate for the National Civil Aviation Agency to list such restrictions in advance. Third, already in appeal, the Federal Regional Court of the 5th Region recognized that, according to a study developed by the Secretariat for Economic Monitoring of the Ministry of Finance (Sae/MF), of the 3rd Coordination and Review Chamber of the Federal Public Ministry (3rd CCF/MPF). In addition to the Legislative Consultancy of the Chamber of Deputies, the sale of airline tickets with checked luggage allowance is of a "tied sale" nature, a circumstance prohibited by article 39, I of the CDC. In this regard, Silva \& Gonçalves (2017) observe that this "grouping of services" - passenger transportation and luggage transportation - referred to in the specialized literature as bundling, obliges the passenger to necessarily pay to take luggage, even if he does not carry any volume. That is, for each and every passenger, both the transportation of a person and his luggage are sold, although only a few are interested in checking luggage ${ }^{9}$.

The costs of transportation services are passed on by the carrier to the user, the amount related to the availability of the checked luggage allowance is shared by all users. However, it is clear that only those who actually use the service should pay for using the transport of volumes. Thus, ANAC regulations are legal by allowing travellers who do not wish to dispatch any volume to purchase tickets where the value of this accessory service is not included.

Concluding the legal arguments favorable to the removal of the mandatory luggage allowance, the 1 st degree merit decision of Public Civil Action no: 0816363-41.2016.4.05.8100 highlights other important arguments presented by the Agency (2017, p. 8):

[...] "currently the imposition of the $23 \mathrm{~kg}$ offered for checked luggage is far beyond the national average, which, according to Technical Note 11/2016 / GEAC / SAS, is below $12 \mathrm{~kg}$ per passenger", arguing that "saying that the transport of luggage is essential to the air transport service is fallacious, whereas $35 \%$ of passengers transported today travel without luggage, according to data from the Civil Aviation Secretariat of the Ministry of Transport, even with this included in the ticket price. In this sense, a state imposition of this value imposes unnecessary costs on the provider of transport services, which are passed on to the consumer. The cost of transporting luggage, in turn, is shared by all, without this having to constitute an obligation on passengers". It further claims that the referred release complies with the principles of freedom of tariffs and freedom to offer routes, which govern air transport contracts, under the terms of Law No. 11,182 / 2005, and that ANAC, contrary to what the author states, subsidized technical and historical elements to edit the regulation in question, specifically with a comparative study of the reality of several other countries, in which it was found that Brazil would be among the most restrictive countries with regard to the regulation of luggage transport, both on domestic as well as international flights, which significantly increases the cost of air transportation for consumers, since "the fare for air tickets includes, by the regulation prior to the Resolution now under attack, among its costs, those pertinent to the luggage dispatch in the franchise maximum allowed $(23 \mathrm{~kg}$ and $2 \times 32 \mathrm{~kg})$ in any period. Certainly, this cost is passed on to the passenger, at any time of the year, on any route and even if he/she checks in less weight luggage or even that he/she does not check luggage." Thus, "the expectation is that the release of the luggage allowance will allow the airline to set fares with different luggage allowances 
and it will be up to the consumer, in his free choice exercise, to choose the one that best suits his profile. It also tends to provide the opportunity cost on the part of the airlines, in order to allow them to manage the hold and cargo transportation, which will contribute to the profitability of a flight and the consequent reduction of prices in passenger transportation".

Thus, in line with the understanding of the Federal Court of the 5th Region, there are no indicative assumptions of legality bias in the provisions of Resolution 400/2016. On the contrary, the maintenance of the "grouping of services" is that, in addition to being out of alignment with liberal market ideas, it violates the national order, according to the diction of article 39, item I of the Consumer Protection Code.

Still, according to Bastos et al (2017), ANAC argues that deregulation favors the creativity and free choice of airlines. Collaborative thinking in other countries, which also allow collection, however, the measure displeased several consumers, in addition to institutions such as the Public Ministry. They then manifested themselves in disfavor of the resolution as it represented a setback in guaranteed rights.

\section{APPLICABILITY OF THEORY OF ECONOMIC REGULATION TO THE REGULATION OF THE LUGGAGE ALLOWANCE}

In the field of applicability of the theory of economic regulation in relation to the consumer of aeronautical services, two large groups are identified, both supported by the argument that consumer protection is a fundamental principle of the economic order, article 170, of the Federal Constitution of 1988. This argument demonstrates, from different perspectives, the need to regulate the dispatch of luggage in the air modal. On the one hand, based on the conception that consumer protection will take place with the evolution of the aeronautical market and in favour of eliminating luggage allowance. On the other, consumer dissatisfaction with prices and quality of services. This confrontation of ideas involves the old discussion about the role of the State in the face of the markets, it supports the confrontations of the conceptions of regulation in the public interest versus economic regulation.

In this scenario, there are those who argue that the dissolution of the luggage handling service will result in immediate benefits for consumers, considering that it will lead to a reduction in the value of tickets. This conclusion is supported by the numbers reached by air navigation after the beginning of the policy of freedom fare.

ANAC concluded that "freedom fare is one of the pillars that support the low prices of airline tickets, social inclusion and the growth of air transport" (BRASIL, 2012, p. 28). According to the figures released at a seminar held in 2012 , the average utilization rate of aircraft ${ }^{10}$ in the transport of domestic passenger improved significantly, from $57 \%$ in 2002 to $70 \%$ in 2011 , and the number of paid passengers transported for the same period rose from 33 to 85 million, with an average growth of $11.2 \%$ per year. 
The Domestic Air Fare Report for the 4th Quarter of 2018 points out that the average air fare ${ }^{11}$ decreased from $R \$ 499.62$ in 2009 to $R \$ 348.46$ in $2018{ }^{12}$ (BRASIL, 2019, p. 13). As a result, the modal, previously very expensive, became popular, demanding greater efficiency from companies in managing their costs and tariffs in the face of new market conditions and competition (BRASIL, 2012, p. 28). This process of popularization ratifies the statistical data of 2018 , in which $6.7 \%$ of the total tickets were sold with fares below R\$ 100.00 and $50.9 \%$ below $\mathrm{R} \$ 300.00$, while the tickets over $\mathrm{R} \$ 1,500.00$ represented only $0.8 \%$ (BRASIL, 2019, p. 12).

Resende (2018, p. 11), in an analysis of the Air Transport Statistical Database (BDETA), found that in the months following the breakdown of the dispatch service, there was a significant and gradual decrease in the average number of luggage checked per passenger and a reduction in more than one kilogram in the average amount of checked luggage per person. In addition, using mathematical and statistical modeling, he found an average reduction of $\mathrm{R} \$$ 14.85 in the price of airfare fares.

However, the checked luggage allowance is not the most determining variable in the calculation of the carrier's expenses and, consequently, in the prices required in the fares. The largest expenditures of aviation companies are with fuels and lubricants, which account for $32.2 \%$ of expenses, and aircraft leasing, insurance and maintenance amounts, corresponding to $20.3 \%$ (BRASIL, 2019, p. 7). In this way, fluctuations in the price of oil or even variations in the exchange rate directly influence the costs of aeronautical service, factors that are independent of companies or consumers.

Consequently, the reduction of air fares is not an immediate consequence of the post-Resolution 400/2016 regime ${ }^{13}$. Fortunately, consumer protection is not only achieved by decreasing the values of products or services, being the limitation to State intervention in the aeronautical services market and the formation of another item of differentiation of services and prices offered for the choice of passengers the positive highlights of the normative instrument.

The reduction in state interventionism, similar to that already practiced in the rest of the world, allows the availability of different offers from transport companies for the free choice of passengers, according to their different needs, preferences and payment disposition $^{14}$ (BRASIL, 2019, p. 8). In other words, fare freedom gives companies the opportunity to apply different prices to transportation services, in order to capture different segments of the public, based on the economic theory of price discrimination.

In his studies of microeconomics, Varian (2015, p. 658) subdivides price discrimination in three degrees. In the first degree, named perfect discrimination, there is the sale of units to

11 Average amount paid by the passenger on a trip to his destination due to the provision of air transport services. The indicators were presented in nominal values and in real values (deflated by the IPCA). Until the making of this article, ANAC had not released the general statistics for 2019.

12 Values related only to the routes monitored by Decrees 1,213 / 2001 / DGAC / 2001 and 447 / 2004 DGAC / 2004. Only from July 2010, when Resolution No. 140/2010 came into force, did all domestic lines begin to be monitored. The "general" airfare as of 2011 also declined, from $R \$ 472.45$ that year to $R \$ 426.54$ in 2018.

13 Assessing the problem, this is how ANAC positioned itself: "The context of the various variables that influence the entire market and the economy in general within a period can be quite different from the other period to be compared.The price difference cannot be expected to be explained by a single factor in isolation. The association of fluctuations in prices to any possible cause, such as the transport of luggage, necessarily depends on a robust time series with several indicators, so that it is possible to isolate the impacts of each variable considered "(2019, p. 9). 
the person who attributes the greatest value to the asset, confirming the transaction only for the maximum price that person is willing to pay. In the second, there is the sale of different units of product at different prices, but each person who buys the same quantity of goods pays the same price (prices differ with respect to units of good, but not with regard to people). And, in the third degree, exemplified in the practice of discounts for elderly people and students when the production is sold to different people with different prices, but each unit sold to a certain person is sold at the same price.

Airlines usually use the second degree of price discrimination (non-linear pricing), notably regarding the distinction between first class and economy class $(2015$, p. 664). By launching different packages, companies provide consumers with an incentive to self-select based on the quality of the offer. The main strategy is to convince the public most likely to pay higher prices to choose the highest quality services and, for that, there is a reduction in the quality of the services offered in the simplest packages.

If there were no consumers of the best quality packages, the economy class would obtain a higher quality product, but at a higher price. On the other hand, without consumers in the economy class, those in the first class would benefit from the reduction in the price charged, however they would register a surplus equal to zero ${ }^{15}$. Fare freedom gives companies the opportunity to explore the relationship with both classes, to which Varian $(2015, \mathrm{p}$. 665 ) observes an important social utility in the price discrimination system, once otherwise companies could decide that it would be great to sell only to high demand markets.

Even so, there are those who resort to the propositions of the regulation theory in the public interest and question the feasibility of the State intervening in the values practiced in checked luggage fees or even in the global-final price, in order to establish maximum amounts for charging consumers ${ }^{16}$. As Trindade (2019, p. 55) explains, the theory of regulation by the public interest incorporates non-economic aspects such as the well-being of the population and the interests of the community. That way, the economic views on the market lose strength in the face of the responsibility of promoting benefits to the general population, especially to consumers. In the present case, the logic would be that "the exclusion of the luggage allowance should excessively burden the vulnerable part of the consumption relationship, unbalancing the subscription contracts of the passenger air transport" (OAB, 2019, p. 3).

It urges to recall that the present work has already demonstrated the negative aspects of luggage allowance, notably by forcing all passengers to pay for the checked luggage even if they are not using it. Furthermore, the legal impracticability of the measure remains clear, since the maintenance of luggage allowance violates the precepts of the Consumer Protection Code, as it is a kind of tie-in sale. The thesis raised by entities, such as the OAB, cease asking who are the real beneficiaries; who bears the burden of regulation; what is the form

15 Consumer surplus is the difference resulting from the consumer purchasing a product for less than the highest price he would be willing to pay. See: http://robguena.fearp.usp.br/Introducao/excedente.imp.pdf

16 There are those who defend the need for the Brazilian State to adopt the price cap regulation technique. According to Investopedia, "price-cap regulation is a form of economic regulation generally specific to the utility industry in the United Kingdom. Price-cap regulations set a cap on the price that the utility provider can charge. The cap is set according to several economic factors, such as the price cap index, expected efficiency savings and inflation". (Https://www.investopedia.com/ terms/p/price-cap-regulation.asp). Observing the proposals to change the regulation of the airline sector, as in the case of the Conversion Bill (PLV) 06/2019, CADE analysed the possible competitive effects of the adoption of this regulatory model for airline ticket prices, detailing its conclusions in Technical Note No. 12/2019/DEE/CADE. 
of this regulation; and, what are the effects of this on the allocation of resources. In fact, Stigler $(2017$, p. 31$)$ undoes the principles of regulation by the public interest exactly through these questions. The American economist argued that the benefits of State intervention in the markets fall short of the losses caused to the rest of the community $(2017$, p. 40). For example, imagine that the regulation of the air sector could, in theory, favor its companies, promote improvements to airports, and improve, in general, the service to consumers. Such a privilege given to the State to a specific sector of the market causes damage to other means of transport, such as road modal, which is a competitor (substitute) for the aeronautical service. Indeed, caution is needed regarding the perception that the State moves imbued with collective values and that this intervention is positive for the social body.

As Trindade instructs (2019, p. 56), state regulation is a "product" shaped from prevailing interests. The point is that, in capitalist systems, the state's interference in the market enhances the propensities of economic agents, often to the detriment of social interests. This is due to the power of influence of these agents to make regulatory acts more palatable or even favorable to their own objectives ${ }^{17}$.

The more the market is adorned with intervening state acts, the greater the likelihood that the regulator will dominate by economic agents. In this way, it could be said that the capture theory ignites an alert similar to the sociological conception of the constitution - proposed by Ferdinand Lassalle - that there are real factors of power that dominate and build the "real constitution". The apparent vision of that regulatory acts are forged only by the public interest vanishes from the discovery that these acts are tied to private interests of small groups, especially economic/financial agents, given the "capture" of the regulator to conceive the regulation desired by the regulated (TRINDADE , 2019, p. 74).

For these reasons, at the end of the luggage allowance in the Brazilian civil aviation market, there is a positive factor for limiting a possible capture by the regulator, since it reduces the possibilities of capture of the regulatory power by the regulated.

\section{FINAL CONSIDERATIONS}

We started this study with the debate about the theory of economic regulation, exploring its main elements, also explaining what it consists of and how it has evolved over the years. Then, we started to analyze the main aspects regarding the regulation of air transport, with emphasis on the United States, considering the great growth experienced by this country in its regulatory experiences.

17 In Posner\&\#39;s view, "a serious problem with any version of the public interest theory is that the theory does not define any exchange or mechanism by which a public interest conception is translated into legislative action.In market theory, it is explained how the efforts of individuals to promote their own interests through transactions generate an efficient allocation of resources. There is no similar articulation of how public opinion about which legislative policies or measures could maximize social welfare is translated into legislative action, it is not enough to just say that the voter will vote for the candidate who promises to develop public policies that voters conceive to be public interest; other policies may benefit a specific voter more.Policies that benefited $51 \%$ of voters could impose much higher costs on the other $49 \%$, a situation in which the majority would be forced to face a conflict between principles and interests - and no theoretical doctrine or empirical evidence suggests that they would probably choose the principles " (2017, p. 64). 
It appears that, historically, the regulation of the Brazilian airline sector, from the 1930s to the present day, the trajectory of state intervention in the sector and, from there, the first attempts to regulate luggage allowance until the edition Resolution 400/2017 are shown. It functioned as a propaedeutic reference for the study we set out to carry out. It is possible to analyze the end of luggage allowance on three perspectives: (a) by the theory of price discrimination; (b) by the consumerist bias; and (c) industry statistics in recent years. First, the elimination of luggage allowance is supported by the theory of price discrimination (second degree discrimination, according to the lessons of Hal Varian), with, therefore, economic-scientific support for the measure. In turn, it is considered a compliance with the consumerist norm, since the aggregation of services (transportation of luggage and people) constituted a type of tie-in sale, a practice prohibited by Law 8.078 / 1990 (article 39, I). Finally, the statistical results of the previous stages of the economic freedom process in the airline sector confirm the effectiveness, for consumers and air transport companies, of promoting greater freedom in this modal.

Moving forward, it is still possible to analyze the measure proposed by Resolution No. $400 / 2016$ for the lessons of the economic theory of regulation, especially regarding the perception of the effects of state intervention in the market and the understanding of the real beneficiaries of state interference, as assessed by the theory of capture. In this sense, the present research demonstrates that the promotion of greater economic freedom is beneficial to the airline industry, as it reduces the effects of the capture of the regulator by sectoral economic agents, so that, however the end of baggage allowance could fit the Theory of Capture a priori, a posteriori the expansion of the economic freedom for companies may result in gains for both consumers and businessmen.

\section{REFERENCES}

BASTOS, Débora Alves Pereira; SILVA, Rodrigo César Bessoni e; LUCAS, Vander Mendes. Desregulamentação da franquia de bagagem despachada no Brasil: Uma Análise de Impacto Regulatório. 2017. Available at: https:// econpolrg.files.wordpress.com/2017/08/eprg-wp-2017-77.pdf. Accessed: Jan 15, 2020.

BRASIL. Agência Nacional de Aviação Civil. Tarifas Aéreas Domésticas - $3^{\circ}$ Trimestre de 2012. Available at: https://www.anac.gov.br/assuntos/setor-regulado/empresas/envio-de-informacoes/tarifas-aereas-domesticas-1/arquivos/relatorio26.pdf. Accessed: Dec 17, 2019.

BRASIL. Agência Nacional de Aviação Civil (ed.). Formulário de análise para proposição de ato normativo. Available at: https://www.anac.gov.br/participacao-social/consultas-publicas/audiencias/2016/aud03/formularioair. pdf/view. Accessed: Ago 21, 2020.

BRASIL. Agência Nacional de Aviação Civil (ed.). Relatório das contribuições da Audiência Pública No 03/2013. Available at: https://www.anac.gov.br/participacao-social/consultas-publicas/audiencias/2016/aud03/ AP032016RAC.pdf/view. Accessed: Ago 21, 2020.

BRASIL. ANAC. Relatório de Tarifa Aérea Doméstica relativo ao $4^{\circ}$ Trimestre de 2018. Available at: https://www. anac.gov.br/assuntos/setor-regulado/empresas/envio-de-informacoes/tarifas-aereas-domesticas-1/relatorio-de-tarifas-aereas-domesticas-nacional. Accessed: Jan 10, 2020.

BRASIL. ANAC. Relatório de tarifa aéreas domésticas $3^{\circ}$ Trimestre de 2019. Available at: https://www.anac.gov. br/assuntos/setor-regulado/empresas/envio-de-informacoes/tarifas-aereas-domesticas-1/relatorio-de-tarifas-aereas-domesticas-nacional. Accessed: Jan 10, 2020. 
BRASIL. ANAC. Resolução n 400, de 13 de dezembro de 2016. Dispõe sobre as Condições Gerais de Transporte Aéreo. Available at: https://www.anac.gov.br/assuntos/legislacao/legislacao-1/resolucoes/resolucoes-2016/ resolucao-no-400-13-12-2016/@@display-file/arquivo_norma/RA2016-0400\%20-\%20Retificada.pdf. Accessed: Dec 10, 2019.

BRASIL. ANAC. Seminário sobre os 10 anos de liberdade tarifária no transporte aéreo doméstico. Available at: https://www.anac.gov.br/assuntos/setor-regulado/empresas/envio-de-informacoes/tarifas-aereas-domesticas-1/seminario-10-anos-de-liberdade-tarifaria-no-transporte-aereo-domestico. Accessed: Jan 10, 2020.

BRASIL. Conselho Administrativo de Defesa Econômica. Nota Técnica nº 12/2019/DEE/CADE. Analisa os possíveis efeitos concorrenciais da adoção de um modelo de regulação price cap para os preços de passagens aéreas. Available at: http://www.cade.gov.br/acesso-a-informacao/publicacoes-institucionais/dee-publicacoes-anexos/nota-tecnica-no-12-2019.pdf/view. Accessed: Dec 15, 2019.

BRASIL. CADE. Nota Técnica n 11/2019/DEE/CADE. Analisa o Projeto de Lei de Conversão (PLV) 6/2019, apresentado pelo senador Roberto Rocha (PSDB-MA) à Medida Provisória (MP) 863/2018, a qual permite o investimento estrangeiro na aviação nacional. Available at: http://www.cade.gov.br/acesso-a-informacao/publicacoes-institucionais/dee-publicacoes-anexos/nota-tecnica-no-11-2019.pdf/view. Accessed: Dec 15, 2019.

BRASIL. Lei n 11.182, de 27 de setembro de 2005. Cria a Agência Nacional de Aviação Civil - ANAC, e dá outras providências. Available at: http://www.planalto.gov.br/CCIVIL_03/_Ato2004-2006/2005/Lei/L11182.htm. Accessed: Dec 10, 2019.

BRASIL. Ministério Público Federal. Parecer Técnico n 197/2016 - Seap. Análise do Setor aéreo. GT-Transportes. Análise das mudanças sugeridas pela ANAC nas Condições Gerais de Transporte Aéreo. Relator: Rodrigo César Bessoni e Silva. Available at: http://www.mpf.mp.br/pgr/documentos/parecer-tecnico-anac. Acesso: Dec 15, 2019.

BRASIL. Tribunal Regional Federal da 5a Região. Proc. n. 0816363-41.2016.4.05.8100. Apelante: Departamento Municipal De Proteção e Defesa Dos Direitos do Consumidor. Apelado: Agencia Nacional de Aviação Civil - ANAC. Available at: http://www5.trf5.jus.br/noticias/320414/trf5_nalo_conhece_pedido_do_conselho_federal_da_oab_ para_suspender_artigos_de_resolua_alo_da_anac.html. Accessed: Dec 10, 2019.

CARRIGAN, Christopher; COGLIANESE, Cary. Capturing Regulatory Reality: stigler's the theory of economic regulation. Stigler's The Theory of Economic Regulation. 2016. Available at: https://papers.ssrn.com/sol3/papers. cfm?abstract_id=2805153. Accessed: Ago 18, 2020.

CHANG, Ha-joon. The economics and politics of regulation. Cambridge Journal Of Economics, Cambridge, n. 21, p.703-728, 1997.

CHMURA, Christine. The Effects of arline regulation. 1987. Available at: https://fee.org/articles/the-effects-of-airline-regulation/. Accessed: Jan 12, 2020.

FIANI, Ronaldo. Afinal, a quais interesses serve a regulação? Economia e Sociedade, Campinas, v. 13, n. 2, p. 81-105, 2004. Available at: http://www.eco.unicamp.br/images/arquivos/artigos/580/Fiani.pdf. Accessed: Ago 19, 2020.

GOWRISANKARAN, Gautam. Competition and regulation in the airline industry. Frbsf Economic Letter, São Francisco, n. 1, p.1-3, Jan 2002.

GUARANYS, Marcelo Pacheco dos. Análise jurídica da política regulatório do transporte aéreo no Brasil (20002010). 2010. 138 f. Dissertação (Mestrado) - Curso de Direito, Faculdade de Direito, Universidade de Brasília, Brasília, 2010.

MONCADA, Luís S. Cabral de. Direito económico. 5. ed. Coimbra: Coimbra, 2007. 708 p.

OLIVEIRA, Alessandro V. M. Performance do regulado e eficácia do regulador: Uma avaliação das políticas regulatórias do transporte aéreo e dos desafios para o futuro. 2007. Available at: http://www.ipea.gov.br/portal/images/ stories/PDFs/arq11_cap06.pdf. Accessed: Jan 12, 2020.

OLIVEIRA, Rafael Carvalho Rezende de. Novo perfil da regulação estatal: Administração pública de resultados s análise de impacto regulatório. 2015. ed. Rio de Janeiro: Forense, 2015. 336 p. 
POSNER, Richard. Teorias da regulação econômica. In: MATTOS, Paulo Todescan Lessa et al (Org.). Regulação econômica e democracia: O debate norte-americano. 2. ed. São Paulo: Revista dos Tribunais, 2017. Cap. 2. p. 57-84

RESENDE, Bruno César Mariano. Estimativas do efeito da taxa de despacho de bagagem. 2018. 38 f. Dissertação (Mestrado) - Curso de Pós-graduação em Economia, Fundação Getúlio Vargas, Rio de Janeiro, 2018. Cap. 7. Available at: https://bibliotecadigital.fgv.br/dspace/handle/10438/25652. Accessed: Jan 10, 2020.

SILVA, E. F.; GONÇALVES, S. S.. A cobrança da bagagem despachada nas viagens aéreas: a quem interessa? Estudo técnico. Câmara dos Deputados. Available at: http://bd.camara.gov.br/bd/handle/bdcamara/34379. Accessed: Jan 05, 2020.

STIGLER, George. A teoria da regulação econômica. In: MATTOS, Paulo Todescan Lessa et al (Org.). Regulação econômica e democracia: O debate norte-americano. 2. ed. São Paulo: Revista dos Tribunais, 2017. Cap. 1. p. $31-55$.

STIGLITZ, Joseph E.; ROSENGARD, Jay K.. Economics of the public sector. 4. ed. Nova lorque: W. W. Norton \& Company, 2015. $961 \mathrm{p}$.

TRINDADE, A. D. C. A teoria da regulação econômica aplicada ao setor mineral brasileiro. Revista de Direito Setorial e Regulatório, v. 5, n. 2, p. 53-78, outubro 2019.

VARIAN, Hal R.. Microeconomia - uma abordagem moderna. 9. ed. São Paulo: Elsevier, 2015. 840 p.

Recebido/Received: 06.06.2020.

Aprovado/Approved: 29.11.2020. 